\title{
Pendampingan Masyarakat Dan Penguatan Moderasi Islam Kepada Masyarakat Sampang Korban Konflik Syi'ah Di Rumah Susun Puspa Agro Sidoarjo
}

\section{Miftahul Ulum}

STAI Syaichona Moh. Cholil Bangkalan

Email: miftahul_ulum2001@yahoo.com

\begin{abstract}
After providing assistance and various discussions, moderation of Islam needs to be carried out continuously especially for the marginalized, especially the people of Syi'ah Sampang and the people who perpetrated the arson and riots in the Sampang Sunni-Shia conflict that occurred seven years ago. As a result of discussions with various approaches that the Syi'ah Sampang community who were displaced in Puspa Agro Flats wanted to get legal certainty and justice and were able to return to their home villages. After the author carried out community assistance to the Sampang community victims of the Sampang Syiah conflict in the Puspa Agro Sidoarjo Flats, the authors concluded that it was necessary to conduct continuous and continuous assistance, given the complexity of changing the mindset and mindset of many people, especially regarding trust or belief in religion.
\end{abstract}

Keyword: Strengthening, Syiah Sampang, Moderation of Islam

\section{Pendahuluan}

Dalam Undang-Undang 1945, setiap warga negara berhak memilih keyakinan sesuai dengan kepercayaannya, hal ini karena hak beragama telah melekat pada setiap warga negara seperti yang tertuang dalam pasal 28 dan 29 bahwa kebebasan beragama dijamin oleh negara. Namun demikian, konflik demi konflik laksana benang kusut yang silih berganti kerap tejadi di bumi pertiwi kita Indonesia tercinta, seakan konflik-konflik tersebut menabrak legitimasi undangundang kita. Rangkaian peristiwa konflik kerap menggelinding begitu saja, seolaholah masifnya kesadaran masyarakat dalam penegakan supremasi hukum.

Hasil beberapa penelitian menyebutkan tentang pluralisme agama yang menyiratkan konflik sosial dan berbagai bentuk ketegangan kerap terjadi, misalnya; 
konflik antara penganut kepercayaan (agama) yang berbega agama, konflik intern sesama penganut kepercayaan, konflik antara penganut agama formal (resmi) dan agama non formal, konflik eksternal yaitu antara penganut kepercayaan (agama) dengan kelompok-kelompok tertentu seperti kelompok adat, kebudayaan, dan kelompok ekonomi tertentu.

Konflik internal antar sesama penganut kepercayaan (agama) yang kerap terjadi di negeri kita seyogyanya dilatarbelakangi oleh banyak faktor, sekalipun tidak ada agama yang menganjurkan untuk berkonflik. Oleh sebab itu, penyebab utama atas realitas konflik adalah faktor kepentingan pribadi atau kepentingan golongan yang menjadi pendorong, pemicu terjadinya berbagai kisruh atau konflik sosial.

Konflik internal antar umat beragama antara lain adalah konflik SunniSyi'ah yang terjadi di Desa Karang Gayam, Kecamatan Omben, Kabupaten Sampang, Madura, Jawa Timur. Ketegangan akibat konflik ini terjadi antara kelompok agama Islam yang berhaluan Syi'ah dan kelompok agama Islam yang berhaluan Sunni sejatinya bukanlah semata-mata disebabkan permasalah perbedaan keyakinan. Konflik yang memprihatinkan dan menyita perhatian berbagai kalangan, baik skala regional, nasional maupun international ini adalah disamping menelan banyak korban jiwa, seluruh rumah warga Syi'ah Sampang dibakar dan rata dengan tanah. Hal ini yang menyebabkan masyarakat Syi'ah Sampang harus mengungsi sejak tersulutnya konflik tersebut hinggga sekarang di Rumah Susun Puspa Agro Sidoarjo. Dengan demikian, kami sebagai bagian dari warga muslim Madura merasa tergerak untuk memberikan perhatian dan pendampingan dalam pengutana moderasi Islam terhadap warga Syi'ah Sampang di Rumah Susun Puspa Agro Sidoarjo.

\section{Metode}

Merujuk pada latar belakang masalah di atas, maka disusunlah berbagai pendekatan dan metode. Metode pendampingan ini adalah metode ABCD (Asset 
Based Community Development).

\section{Hasil dan Diskusi}

\section{Profil Lokasi dan Target Sasaran Program}

Sejak awal, sejatinya pemerintah Propinsi Jawa Timur telah menyediakan ratusan kamar untuk para pengungsi warga Syiah Sampang di Rumah Susun Puspa Agro, Taman Sidoarjo. Setidaknya sekitar 500 orang warga Syi'ah Sampang telah menempati rumah susun ini. Pemerintah telah menyediakan tempat tersebut tidak hanya bagi para pengungsi Syi'ah Sampang saja, melainkan bagi para imigran yang datang dari berbagai negara yang sedang konflik, seperti pengungsi dari Afghanistan, Suriah, Sudan, Pakistan, Myanmar, Srilangka dan lain sebagainya.
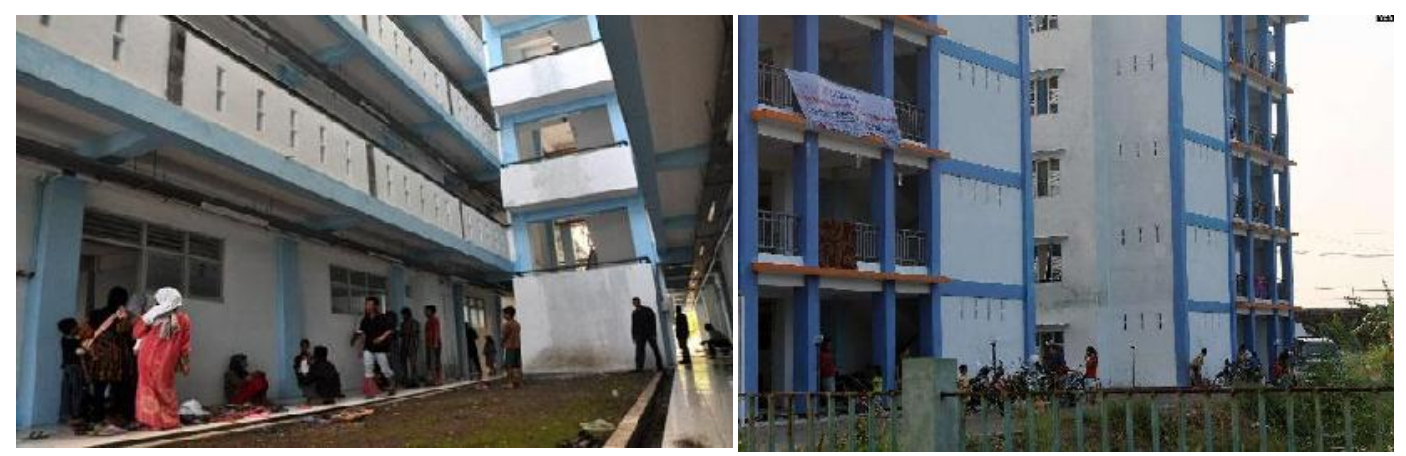

\section{Gambar 1. Rusun Puspa Agro}

Tahun 2019 adalah tahun ke tujuh bagi warga Syi'ah Sampang Madura harus tetap mengungsi dan meninggalkan kampung halaman mereka dan memasuki tahun ke lima sebagai penghuni Rumah Susun Puspa Agro Sidoarjo. Sempat tercium khabar bahwa warga pengungsi Syi'ah akan direlokasi ke luar pulau Jawa atau ke suatu lokasi di kawasan Surabaya, namun warga Syi'ah Sampang menolak.

\section{Pendampingan Moderasi Islam}

Diskusi hangat antara pendamping dengan tokoh Syi'ah Sampang serta segenap warga Syi'ah di Rumah Susun Puspa Agro Sidoarjo mengalir dengan baik, ketika pendamping mencoba mendekati dengan pendekatan Hadits, Rasulullah 
Muhammad SAW pernah bercerita di tengah-tengah sahabatnya bahwa golongan yang benar hanya golongan Ahlu Sunnah Wal-Jamaah, dengan penjelasan hadits berikut:

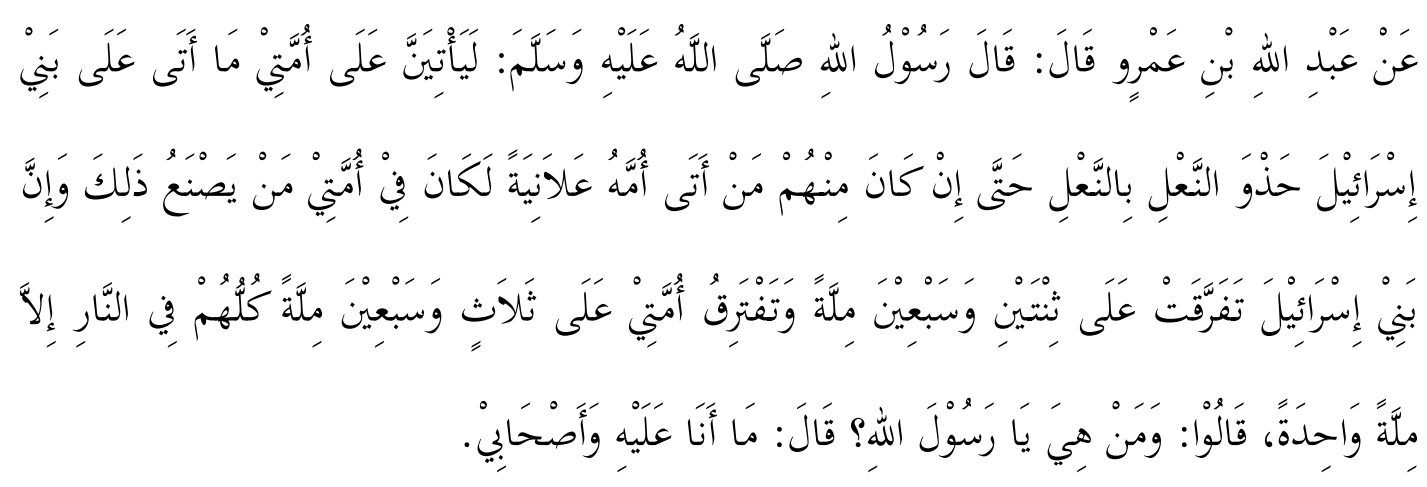

Dari "Abdullah bin 'Amr, ia berkata: "Rasulullah Shallallahu 'alaihi wa sallam bersabda, 'Sungguh akan terjadi pada ummatku, apa yang telah terjadi pada ummat bani Israil sedikit demi sedikit, sehingga jika ada di antara mereka (Bani Israil) yang menyetubuhi ibunya secara terang-terangan, maka niscaya akan ada pada ummatku yang mengerjakan itu. Dan sesungguhnya bani Israil berpecah menjadi tujuh puluh dua millah, semuanya di Neraka kecuali satu millah saja dan ummatku akan terpecah menjadi tujuh puluh tiga millah, yang semuanya di Neraka kecuali satu millah.' (para Shahabat) bertanya, 'Siapa mereka wahai Rasulullah?' Beliau Shallallahu 'alaihi wa sallam menjawab, 'Apa yang aku dan para Shahabatku berada di atasnya."” (Hadits Riwayat at-Tirmidzi no. 2641).

Menanggapi hadits tersebut, maka Ustad Tajul sebagai guru dan penanggung jawab warga Syi'ah Sampang menjawab bahwa hadits tersebut derajadnya shahih dan beliau menegaskan bahwa Syi'ah merupakan bagian dari Ahlu Ash Sunnah Waljama'ah, "kami juga tahlilan seperti layaknya warga Nahdiyyin bahkan tahlilan kami lebih lama dari mereka”, sambung Tajul, beliau juga bercerita tentang sejarah Syi'ah mulai zaman Sahabat Nabi hingga sekarang. Disisi lain, salah satu warga Syi'ah Sidoarjo yang tidak mau disebutkan namanya mengklaim bahwa "jutru Ahlu Assunnah bagian dari Syi'ah, semua itu sumbernya dari Syi'ah, coba sampeyan lihat budaya-budaya Syi'ah seperti Maulid Nabi Muhammad, Tahlil, Haul”, pungkas beliau.

Ketika pendamping mencoba mendekati dengan logika sederhana bahwa 
pendamping bercerita tentang banyaknya jasad para Sahabat-Sahabat Nabi Muhammad penganut Ahlu Sunnah Wal Jama'ah yang jasadnya masih utuh sehingga sekarang, atau dikalangan Sunni pada era kini yang meninggal puluhan tahun lalu yang jasadnya masih utuh sampai sekarang sebagai salah satu indikator bahwa amal mereka diterima, maka Ustad Tajul juga menjawab bahwa "Jasad Sahabat penganut Syi'ah mulai jaman Sahabat banyak yang masih utuh sehingga sekarang, terbukti setelah banyaknya jasad para Sahabat penganut Syi'ah dengan adanya bom yang salah sasaran menuju areal pemakaman dan meluluh lantahkan areal pemakaman di Iraq, Yaman, atau di Jazirah Arab yang lain, dan ternyata banyak jasad para Sahabat penganut Syi'ah yang jasadnya masih utuh, berabadabad lamanya" pungkas Tajul. Sebagian warga Syi'ah berkomentar, "saya juga pernah menyaksikan bahwa salah satu jasad warga Syi'ah yang meninggal beberapa puluh tahun lalu juga masih utuh sampai sekarang, tebukti ketika saya mengantarkan jenazah ke areal pemakaman, tak sengaja makam warga Syi'ah terbuka dengan sendirinya akibat pengglian makam yang berdekatan”, sambung penjelasan salah satu warga Syi'ah. Wallahu A'lam.

Menurut pengakuan Tajul Muluk tokoh Syi'ah Sampang bahwa "warga Syi'ah Sampang menginginkan untuk kembali ke kampung asal mereka dan secara undang-undang kami memiliki hak yang sama serta melekat bagi setiap warga negara yang harus dilindungi karena setiap warga negara memiliki hak, kedudukan dan kewajiban sama”, pungkas Tajul.

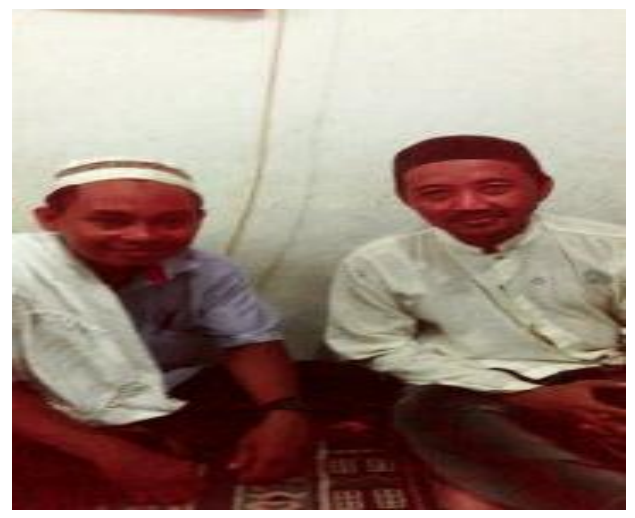

Gambar 2. Dr. Miftahul Ulum dengan tokoh Syi'ah Sampang

Volume 2, Nomor 1, November 2019 


\section{Diskusi Tentang Sejarah Syi'ah Sampang}

Berdasarkan hasil diskusi dengan Ustad Tajul Muluk dan beberapa warga Syi'ah Sampang di Rumah Susun Puspa Agro Sidoarjo bahwa asal muasal komunitas Syi'ah Sampang bermula dari kekaguman seorang tokoh Sunni Sampang bernama kyai Maimun terhadap jayanya negara Islam Iran. Kekaguman ini berlanjut dengan mengantarkan tiga orang putranya ke sebuah pesantren yang merupakan representasi haluan Syi'ah di Bangil (YAPI) Kabupaten Pasuruan Jawa Timur. Ketiga putra Kyai Maimun tersebut antara lain: Iklil al Milal, Ali Murtadha alias Tajul Muluk, dan Ummi Hani. Untuk memperdalam ilmunya, Tajul Muluk melanjutkan pendidikan ke Ma'had Pimpinan Sayyid Muhammad Al-Maliki di Makkah, "pesantren ini murni berhaluan Sunni", terang Tajul. Tajul juga mengaku bahwa ia pernah menimba ilmu di Repubik Islam Iran.

Sepulang dari Arab, Tajul mendirikan Madrasah bernama Madrasah Misbahul Huda. Madrasah ini fokus memberdayakan dan memanfaatkan SDM (Sumber Daya Manusia) tamatan pesantren YAPI Bangil Kabupaten Pasuruan. Dalam rentan waktu yang relatif sangat singkat, pengikut Tajul berjumlah ratusan orang, "hanya sekitar 3 tahun”, ungkap Tajul.

Tajul rela berdakwah tanpa pamrih, Tajul menolak amplop (bisyaroh) setelah berceramah, atau diskusi tentang agama kecuali jika dipaksa. Tajul juga ringan tangan dan suka membantu masyarakat yang membutuhkannya sehingga dalam waktu yang sangat singkat menyemai pengikut hingga ratusan orang. Dan Tajul tidak menanamkan rasa dendam kepada para pengikutnya atas pihak-pihak yang telah mendzhaliminya, seperti korban pembunuhan atas tragedi berdarah tujuh tahun silam di desa kelahirannya, Desa Karang Gayam. "Yang lalu biarlah berlalu, kami tidak dendam, kami hanya ingin kembali ke kampung halaman kami”, imbuh Tajul seraya sangat berharap kembali ke Desa asalnya. 


\section{Kesimpulan}

Setelah melakukan pendampingan dan berbagai diskusi, moderasi Islam perlu dilaksanakan secara terus menerus utamanya bagi kaum marjinal, khususnya masyarakat Syi'ah Sampang dan masyarakat pelaku pembakaran dan kerusuhan konflik Sunni-Syiah Sampang yang telah terjadi pada tujuh tahun silam. Sebagai hasil diskusi dengan berbagai pendekatan bahwa masyarakat Syi'ah Sampang yang mengungsi di rumah Susun Puspa Agro ingin mendapatkan kepastian hukum dan keadilan serta dapat kembali ke desa asal mereka.

Setelah penulis melaksanakan pendampingan masyarakat kepada masyarakat Sampang korban konflik Syi'ah Sampang di Rumah Susun Puspa Agro Sidoarjo, maka penulis berkesimpulan bahwa perlu dilakukan pendampingan lagi secara berkesinambungan dan berkelanjutan, mengingat begitu rumitnya mengubah pola pikir dan mindset masyarakat banyak, apalagi berkaitan dengan kepercayaan atau keyakinan dalam beragama.

\section{Daftar Pustaka}

Abidin, Zainal. 2012. Imamah dan Implikasinya dalam Kehidupan Sosial, Telaah atas pemikiran Teologi Syi'ah. Jakarta: Intigraf.

Abu Zahra. Imam Muhammad. 1996. Tarikh al-Mazahib al-Islamiyah, diterjemahkan oleh Abdurrahman Dahlan dengan judul "Aliran Politik dan Akidah Islam". Jakarta: Logos Publishing House.

Abdun, Abdullah. 1999. Perbedaan Prinsip Antara Akidah dan Ajaran Ahlussunnah Waljamaah dan Syi'ah Imamiyah. Malang: Majelis Dakwah Ahlussunnah.

Alkaf, Halid. 2012. Quo Vadis Liberalisme Islam Indonesia. Jakarta: Penerbit Buku Kompas.

Aris Masruchi, Zainal. 2002."Eksistensi Syi'ah di Indonesia: Wacana Tentang Konstelasi Reaksi Sunni Terhadap Faham Syi'ah di Indonesia”. Skripsi tidak diterbitkan, program sarjana UIN Sunan Kalijaga Yogyakarta. 
48 | Pendampingan Masyarakat Dan Penguatan Moderasi Islam.....

Azra, Azyumardi. 1999. Konteks Berteologi di Indonesia: Pengalaman Islam. Jakarta: Paramadina.

Bakar Aceh, Abu. 1980. Perbandingan Mazhab Syi'ah Rasionalisme dalam Islam. Semarang: Ramadhani.

Coser, Lewis. 1956. The Function Of Social Conflict. New York: The Free Press.

Effendi, Bahtiar. 1998. Islam dan Negara, Transformasi Pemikiran Islam dan Praktik Islam di Indonesia. Jakarta: Paramadina.

Enayat, Hamid. 1982. Reaksi Politik Sunni dan Syi'ah, Pemikiran Politik Islam Modern Menghadapai Abad ke-20. Bandung: Pustaka.

Fauzi, Ahmad. 2013. Merajut Kedamaian Sampang, harian umum Koran Tempo, 1 November 2013.

Fromm, Erich. 1973. The Anatomy of Human Destructivenes. Canada: Library of Congress-Cataloging in Publication Data.

Hasem. 1987. Saqifah Awal Perselisihan Umat. Bandar Lampung: YAPI.

Haarscher, Guy. 2002. Freedom of Religion in Context. BYU Law Review.

Ibnu Faris Ibn Zakariah, Abu Husain. 1994. Mu'jam al-Muqayyis fi al-Lughah. Beirut: Darl al-Fikr.

Jamal al-Din Muhammad Ibnu Makram Ibnu Manzur, Abu Al-Fadl. 1410 H. Lisan Al-Arab, Beirut: Darul Fikr.

Maryam, Siti. 2012. Damai dalam Budaya, Integrasi Tradisi Syi'ah dalam Komunitas Ahlussunnah waljamaah di Indonesia. Jakarta: Badan Litbang dan Diklat Kementrian Agama RI.

Ma'luf, Luis. 1967. Al-Munjid fi al-Lughah. Beirut: Darul Masyriq.

Minorsky, Vladimir. 1983. Iran: Oposisi, Kesyahidan dan Pemberontakan, dalam Gustave E. Von Grunebaum, Islam Kesatuan dalam Keragaman, terjemahan Effendi Yahya, Jakarta: Yayasan Perkhidmatan.

Muhammad Ibnu Karim ibnu Abi Ahmad al-Syahraytani, Abi Fath. Tt. Al-Milal wa An-Nihal, Beirut: Darl Fikr.

M Jafri, Husain. 1989. Awal dan Sejarah Perkembangan Islam Syi'ah dari Saqifah 
sampai Imamah. Jakarta: Pustaka Hidayah.

Rahmad, Miftah F. 1998. Catatan Kang Jalal, Visi, Media, Politik, dan Pendidikan. Bandung Remaja Rosdakarya.

Rahman, Fazlur. 1999. Islam and Modernity: Transformation of an Intellectual Tradition, Chicago: The university of Chicago Press.

Suriati, Nursyam. 2011. Keberlanjutan dan Tradisi Keberagamaan Syi'ah, Studi Pada Masyarakat Santri YAPI Bangil Pasuruan, tesis tidak diterbitkan, program Pascasarjana UIN Maulana Malik Ibrahim.

Syafii Mufid, Ahmad. 2012. Syi'ah di Sampang, Jakarta: Majelis Intelektual dan Ulama Muda Indonesia.

Taufiqurrahman. "Islam dan Budaya Madura", disampaikan dalam Seminar Keberagamaan Orang Madura di STAIN Pamekasan Madura, pada tanggal 19 November 2008

Thabathaba'i. 1989. Islam Syi'ah: Asal usul dan Perkembangannya, terjemahan Djohan Efendi. Jakarta: Pustaka Umum Grifiti.

Wiyata, A Latief. 2002. Carok; Konflik Kekerasan dan Harga Diri Orang Madura, Yogyakarta: LkiS.

------------------. 2003. Madura yang Patuh? Kajian Antropologi Mengenai Budaya Madura, Jakarta: CERIC-FISIP UI.

Zainuddin, Rahman. 2000. Syi'ah dan Politik di Indonesia, Sebuah Penelitian. Bandung: Mizan. 
50 | Pendampingan Masyarakat Dan Penguatan Moderasi Islam..... 